\title{
KORELASI PENDAPATAN KELUARGA DAN PENDIDIKAN IBU TERHADAP PEMBERIAN ASI EKSKLUSIF
}

\section{(Correlation between family income and mother education on exclusive breastfeeding)}

\author{
Faricha Kurnia Illahi ${ }^{1}$ Yusuf Alam Romadhon ${ }^{2}$, Yuni Prastyo Kurniati ${ }^{2}$, Tri Agustina ${ }^{2}$ \\ ${ }^{1}$ Mahasiswa Fakultas Kedokteran Universitas Muhammadiyah Surakarta \\ ${ }^{2}$ Dosen Fakultas Kedokteran Universitas Muhammadiyah Surakarta \\ Email: farichakurnia1904@gmail.com \\ Korespondensi: Tri Agustina. Email: ta190@ums.ac.id
}

\begin{abstract}
Exclusive breastfeeding based on Government Regulation Number 33 of 2012 concerning Exclusive Breastfeeding is breast milk that is given to babies from birth for six months, without adding and or replacing with other food or drinks. Coverage of infants gets exclusive breastfeeding nationally at $61.33 \%$. This figure has exceeded the 2017 Strategic Plan target of $44 \%$. The percentage of exclusive breastfeeding for infants 0-6 months in Central Java in 2017 was $54.4 \%$. Coverage of exclusive breastfeeding in Sukoharjo Regency is $60.36 \%$. The purpose of this research aims to determine whether there is a correlation between the level of family income and level of mother education of excluxive breastfeeding. This research use analytic observational design with cross sectional approach. The population in this study are mothers who have children more than six month in the working area of Gatak Sukoharjo Public Health Center. Sampling technique in this research using cluster random sampling technique. Logistic Regression test data obtained significance of family income level equal to 0.034 and mother education level equal to 0.004. The limitation of this study is to collect data on the level of family income based only on interviews without any supporting questionnaireBased on these results indicate the correlation of family income level and mother education level of excluxive breastfeeding.
\end{abstract}

Keywords: level of education, level of income, exclusive breastfeeding

\section{Abstrak}

ASI eksklusif berdasarkan Peraturan Pemerintah Nomor 33 Tahun 2012 tentang Pemberian Air Susu Ibu Eksklusif adalah ASI yang diberikan kepada bayi sejak dilahirkan selama enam bulan, tanpa menambahkan dan atau mengganti dengan makanan atau minuman lain. Cakupan bayi mendapat ASI eksklusif secara nasional sebesar 61,33\%. Angka tersebut sudah melampaui target Renstra tahun 2017 yaitu 44\%. Persentase pemberian ASI eksklusif pada bayi 0-6 bulan di Jawa Tengah pada tahun 2017 sebesar 54,4\%. Cakupan pemberian ASI eksklusif di Kabupaten Sukoharjo sebesar $60,36 \%$. Tujuan penelitian ini untuk mengetahui adakah hubungan tingkat pendapatan keluarga dan tingkat pendidikan ibu terhadap pemberian ASI eksklusif. Penelitian ini menggunakan desain observasional analitik dengan pendekatan cross sectional. Populasi dalam penelitian ini adalah ibu yang memiliki anak dengan usia lebih dari enam bulan di wilayah kerja Puskesmas Gatak Sukoharjo. Teknik pengambilan sampel dalam penelitian ini menggunakan teknik cluster random sampling. Data uji Regresi Logistik didapatkan signifikansi tingkat pendapatan keluarga sebesar 0,034 dan tingkat pendidikan ibu sebesar 0,004. Keterbatasan penelitian ini adalah melakukan pengambilan data mengenai tingkat pendapatan keluarga hanya berdasarkan wawancara saja tanpa adanya kuisioner lain yang mendukung. Kesimpulan penelitian ini terdapat hubungan antara tingkat pendapatan keluarga dan tingkat pendidikan ibu terhadap pemberian ASI eksklusif.

Kata Kunci: tingkat pendapatan, tingkat pendidikan, ASI eksklusif 


\section{Pendahuluan}

Air susu ibu (ASI) merupakan emulsi lemak dalam larutan protein, laktosa, dan garam-garam organik yang disekresikan oleh kedua kelenjar payudara ibu, serta makanan yang ideal untuk masa pertumbuhan bayi. ASI mengandung zat kekebalan, zat anti infeksi, immunoglobulinA, dan laktoferin ${ }^{2}$ ASI eksklusif adalah ASI yang diberikan dari ibu kepada bayi tanpa penambahan cairan lain atau padatan dengan pengecualian tetes atau sirup yang terdiri dari vitamin, suplemen mineral, atau obat-obatan untuk enam bulan pertama 9 .

Cakupan bayi mendapat ASI eksklusif secara nasional sebesar 61,33\%. Angka tersebut sudah melampaui target Renstra tahun 2017 yaitu $44 \% 5$. Persentase pemberian ASI eksklusif pada bayi 0-6 bulan di Jawa Tengah pada tahun 2017 sebesar 54,4\% ${ }^{6}$. Cakupan pemberian ASI eksklusif di Kabupaten Sukoharjo sebesar $60,36 \%{ }^{1}$. Menurut penelitian Sihombing pada tahun 2018, ada hubungan yang bermakna antara pendidikan ibu dengan pemberian ASI eksklusif. Pendidikan orang tua atau keluarga terutama ibu bayi merupakan salah satu faktor yang penting dalam pemberian ASI Eksklusif pada bayi. Tingkat pendidikan yang rendah akan sulit menerima arahan Dinkes dalam pemberian ASI eksklusif. Tingkat pendidikan yang baik akan lebih mudah dalam menyerap informasi terutama tentang pemenuhan kebutuhan nutrisi anak sehingga akan menjamin kecukupan gizi anak ${ }^{10}$. Akan tetapi pada penelitian Hastuti dkk pada tahun 2015 menjelaskan bahwa dalam penelitiannya mengenai hubungan tingkat pendidikan ibu dengan pemberian ASI eksklusif, tidak terdapat hubungan antara pendidikan ibu dengan pemberian ASI eksklusif.

Pendapatan keluarga merupakan salah satu faktor yang berhubungan dengan kondisi keuangan yang menyebabkan daya beli untuk makanan tambahan menjadi lebih besar. Pendapatan keluarga menyangkut besarnya penghasilan yang diterima, yang jika dibandingkan dengan pengeluaran, masih memungkinkan ibu untuk memberikan makanan tambahan bagi bayi usia kurang dari enam bulan ${ }^{7}$. Penelitian yang dilakukan Maulida pada tahun 2015 menjelaskan bahwa terdapat hubungan yang signifikan antara tingkat ekonomi dengan pemberian ASI eksklusif. Akan tetapi berdasarkan penelitian Nilakesuma dkk tahun 2015 menjelaskan bahwa tidak ada hubungan yang bermakna antara status ekonomi keluarga dengan pemberian ASI eksklusif.

Tujuan dari penelitian ini yaitu untuk mengetahui hubungan tingkat pendapatan keluarga dan tingkat pendidikan ibu terhadap pemberian ASI eksklusif.

Metode

Penelitian ini sudah mendapat ijin dari Puskesmas Gatak Sukoharjo, Dinas Kesehatan Kabupaten Sukoharjo, dan telat terdaftar di komisi etik RSUD Dr. Moewardi dengan nomor Ethical Clearance 1519/XII/HREC/2019. 
Pada penelitian ini menggunakan desain penelitian analitik observasional dengan pendekatan studi cross sectional untuk mempelajari adanya hubungan atau perbedaan prevalensi antar kelompok yang diobservasi. Teknik pengambilan sampel secara cluster random sampling yang sudah mempunyai kriteria inklusi dan eksklusif sendiri sebagai berikut. Kriteria inklusi ibu yang memiliki balita berusia $>6$ bulan, responden berdomisili di wilayah Sukoharjo, dan bersedia menjadi responden. Kriteria eksklusi responden yang tidak hadir di posyandu dan responden tidak mengisi kuesioner secara lengkap. Responden terdiri dari 80 responden. Pengambilan data dilakukan dengan cara wawancara dan pengisian kuisioner oleh responden yang dilaksanakan di Posyandu wilayah Sukoharjo. Analisis data dilakukan secara bertahap, yaitu diawali dengan analisis bivariat menggunakan uji chi-square, dengan ketentuan nilai sig (p) $<0,05$ maka dikatakan terdapat hubungan yang signifikan, apabila nilai sig (p) $\searrow 0,05$ maka dikatakan tidak memiliki hubungan yang signifikan. Analisis data multivariat dilakukan bila memenuhi syarat untuk mengetahui hubungan tingkat pendapatan keluarga dan tingkat pendidikan ibu terhadap pemberian ASI eksklusif dilakukan dengan menggunakan uji regresi logistik

\section{Hasil dan Pembahasan}

Responden dalam penelitian ini berjumlah 80 orang dan sampel yang memenuhi kriteria restriksi adalah 80 orang dengan karakteristik seperti dalam tabel 1.

Tabel 1. Distribusi Karakteristik responden

\begin{tabular}{|c|c|c|c|}
\hline Karakteristik & & Frekuensi & Persentase $(\%)$ \\
\hline \multirow{3}{*}{ Usia } & $<40$ tahun & 77 & $96,30 \%$ \\
\hline & $>40$ tahun & 3 & $3,80 \%$ \\
\hline & Total & 80 & $100 \%$ \\
\hline \multirow{4}{*}{ Tingkat Pendidikan Ib } & Rendah & 27 & $33,80 \%$ \\
\hline & & & \\
\hline & Tinggi & 53 & $66,30 \%$ \\
\hline & Total & 80 & $100 \%$ \\
\hline \multirow{3}{*}{ Status pekerjaan ibu } & Bekerja & 24 & $30 \%$ \\
\hline & Tidak bekerja & 56 & $70 \%$ \\
\hline & Total & 80 & $100 \%$ \\
\hline Tingkat pendapatan & Rendah & 17 & $21,30 \%$ \\
\hline
\end{tabular}




$\begin{array}{lcrr} & \text { Tinggi } & 63 & 78,80 \% \\ & \text { Total } & & 100 \% \\ \text { ASI eksklusif } & \text { Ya } & 80 & 48,80 \% \\ & \text { Tidak } & 39 & 51,20 \% \\ & \text { Total } & 81 & 100 \%\end{array}$

Berdasarkan data tabel 1 usia ibu dikategorikan menjadi dua yaitu kurang dari 40 tahun dan lebih dari 40 tahun. Untuk usia di bawah 40 tahun sebanyak 77 responden $(96,3 \%)$ dan untuk usia di atas 40 tahun sebanyak 3 responden $(3,8 \%)$.

Untuk tingkat pendidikan ibu dikategorikan dalam pendidikan rendah dan pendidikan tinggi. Pada pendidikan rendah didapatkan hasil sebanyak 27 responden $(33,8 \%)$ dan pada responden dengan pendidikan tinggi didapatkan hasil sebanyak 53 responden $(66,3 \%)$.

Pada kriteria status pekerjaan ibu dikategorikan menjadi ibu yang bekerja dan ibu yang tidak bekerja. Ibu yang bekerja didapatkan hasil sebanyak 24 responden dengan persentase $30 \%$

Tabel 2. Hasil Analisis Bivariat

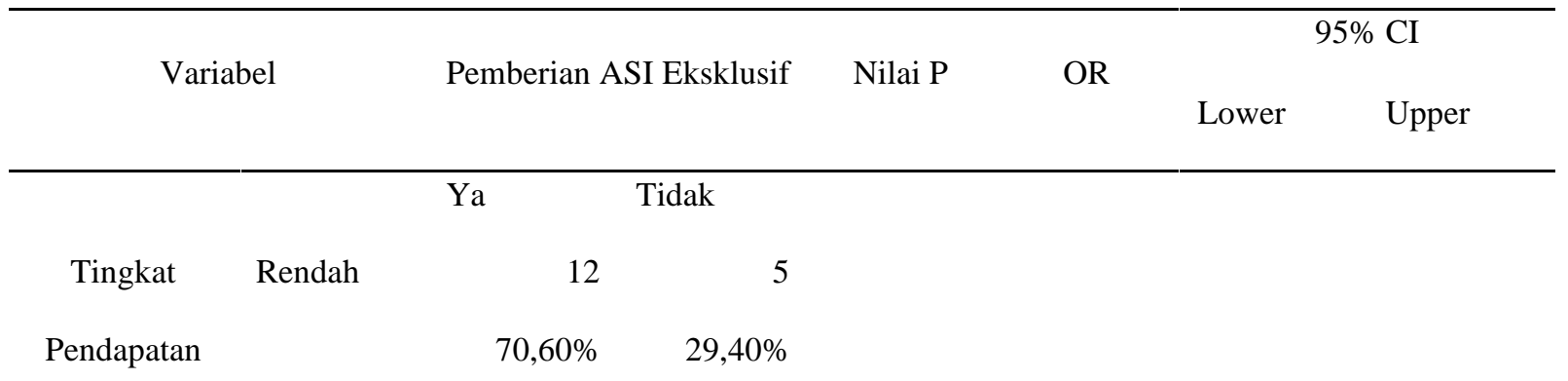

dan untuk ibu yang tidak bekerja didapatkan hasil sebanyak 56 responden dengan persentase $70 \%$.

Data berdasarkan tingkat pendapatan keluarga dikategorikan menjadi pendapatan rendah dan pendapatan tinggi. Untuk pendapatan rendah didapatkan hasil sebanyak 17 responden $(21,3 \%)$ sedangkan untuk pendapatan tinggi didapatkan hasil sebanyak 63 responden $(78,8 \%)$.

Untuk data pemberian ASI eksklusif dikategorikan penjadi ASI eksklusif dan tidak ASI eksklusif. Kemudian didapatkan hasil untuk data yang tidak ASI eksklusif sebanyak 41 responden $(51,2 \%)$ sedangkan untuk data yang ASI eksklusif didapatkan hasil sebanyak 39 responden $(48,8 \%)$. 


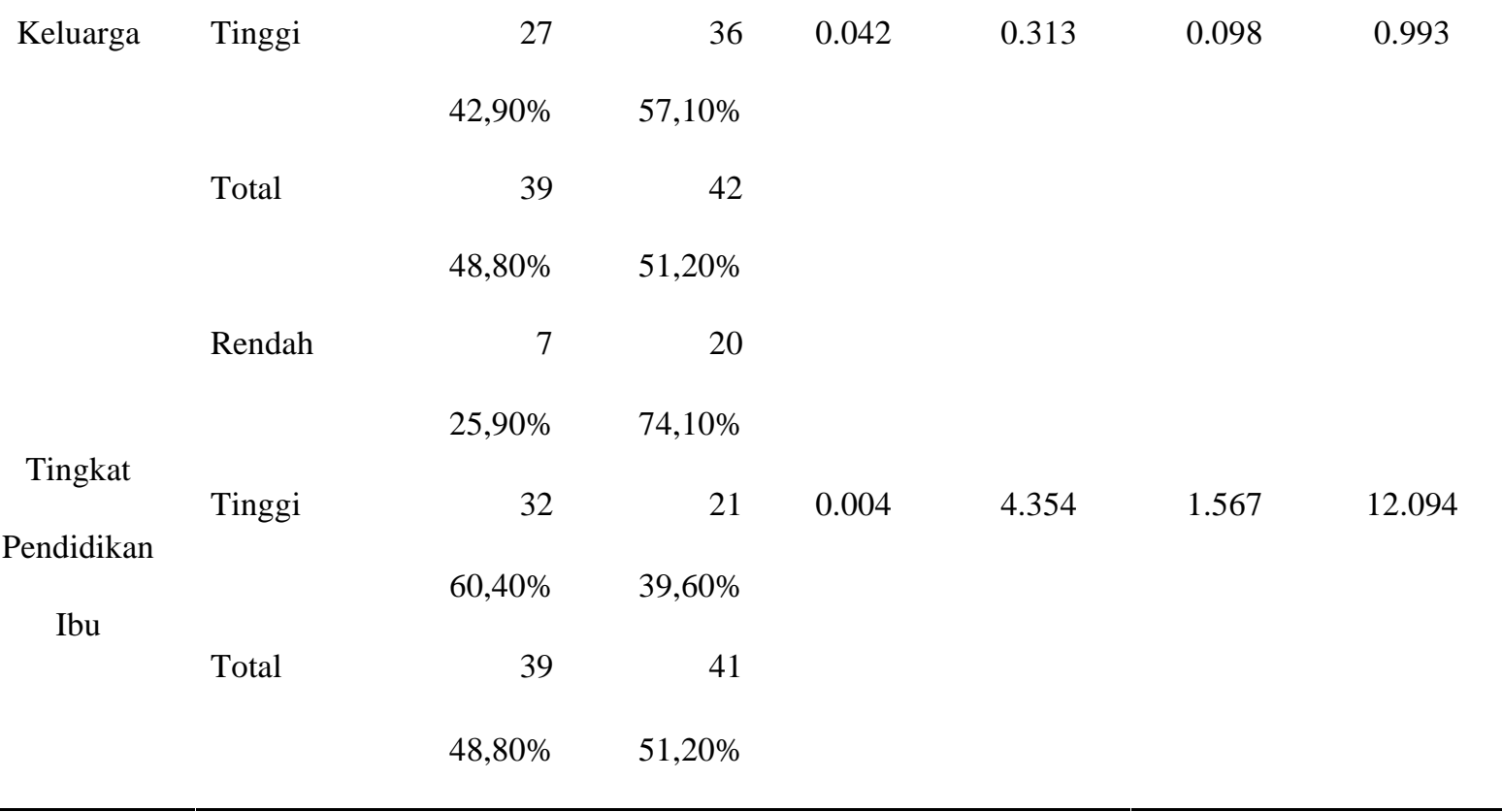

Data pada tabel 2 menunjukkan bahwa responden dengan tingkat pendapatan keluarga rendah yang memberikan ASI eksklusif sebanyak 12 responden (70,6\%) dan yang tidak memberikan ASI eksklusif sebanyak 5 responden $(29,4 \%)$, responden dengan tingkat pendapatan tinggi yang memberikan ASI eksklusif sebanyak 27 responden $(42,9 \%)$ dan yang tidak memberikan ASI eksklusif sebanyak 36 responden $(57,1 \%)$ dengan nilai $p(0,042)$, OR (0,313), dan 95\% CI $(0,098-0,993)$. Nilai p menunjukkan adanya hubungan yang signifikan antara tingkat pendapatan keluarga dengan pemberian ASI eksklusif. Hasil pada penelitian ini sejalan dengan penelitian Hety tahun 2018 menunjukkan bahwa responden dengan tingkat ekonomi tinggi cenderung memiliki minat rendah dalam pemberian ASI eksklusif, sedangkan responden dengan tingkat ekonomi rendah cenderung memberikan ASI Eksklusif. Berdasarkan uji spearman rho diperoleh hasil perhitungan dengan nilai signifikan $\rho=0,001$ sedangkan $\alpha=0,05$. Oleh karena nilai signifikan lebih kecil dari $\alpha$ maka $\mathrm{H} 1$ diterima artinya ada hubungan tingkat ekonomi terhadap pemberian ASI Eksklusif pada bayi usia 0-6 bulan di Desa Salen Kecamatan Bangsal Kabupaten Mojokerto. Kebanyakan keluarga dengan ekonomi kelas atas cenderung mempunyai minat rendah untuk memberikan ASI eksklusif dikarenakan menurut mereka yang mempunyai penghasilan lebih memilih untuk memberikan susu formula kepada bayi untuk mencukupi nutrisi pada bayinya. Faktor ekonomi berkaitan erat dengan konsumsi makanan atau dalam penyajian makanan keluarga khususnya dalam pemberian $\mathrm{ASI}^{4}$.

Responden dengan tingkat pendidikan rendah yang memberikan ASI eksklusif sebanyak 7 responden $(25,9 \%)$ dan yang tidak memberikan ASI eksklusif sebanyak 20 responden $(74,1 \%)$, responden 
dengan tingkat pendidikan tinggi yang memberikan ASI secara eksklusif sebanyak 32 responden $(60,4 \%)$ dan yang tidak memberikan ASI eksklusif sebanyak 21 responden $(39,6 \%)$ dengan nilai $\mathrm{p}(0,004)$, OR $(4,354)$, dan $95 \%$ CI (1,567-12,094). Nilai $p$ ini menunjukkan adanya hubungan yang signifikan antara tingkat pendidikan ibu terhadap pemberian ASI eksklusif. Pendidikan diperlukan untuk mendapat informasi yang dapat menunjang kehidupannya sehingga dapat meningkatkan kualitas hidup seseorang. Pendidikan seseorang berhubungan dengan kehidupan sosialnya. Semakin tinggi pendidikan, maka seseorang tersebut akan lebih memperhatikan masalah kesehatannya. Oleh sebab itu ibu dengan pendidikan tinggi akan cenderung memiliki pengetahuan yang baik tentang ASI eksklusif, dan sebaliknya ibu yang memiliki pendidikan rendah cenderung sulit untuk menyerap informasi khususnya pengetahuan tentang ASI eksklusif sehingga menyebabkan sikap tidak peduli terhadap program kesehatan ${ }^{10}$. Penelitian ini sejalan dengan penelitian Sihombing tahun 2018 menyatakan bahwa ada hubungan yang bermakna antara pendidikan ibu dengan pemberian ASI Eksklusif di Wilayah Kerja Puskesmas Hinai kiri.

Tabel 3. Hasil Analisis Multivariat

\begin{tabular}{lllllll}
\hline Variabel & B & S.E & Wald & Df & Sig & Exp(B) \\
\hline Pendapatan keluarga & -1.370 & 0.645 & 4.513 & 1 & 0.034 & 0.254 \\
Pendidikan ibu & 1.606 & 0.553 & 8.432 & 1 & 0.004 & 4.983 \\
\hline
\end{tabular}


Tabel 3 merupakan hasil dari analisis secara multivariat dengan uji regresi logistik. Berdasarkan uji regresi logistik multivariat, didapatkan hasil signifikan yaitu dengan nilai $\mathrm{p}<0,05$ meliputi pendapatan keluarga $(p=0,034)$ dan pendidikan ibu $(\mathrm{p}=0,004)$. Kekuatan hubungan pada hasil uji multivariat dapat diketahui dari nilai OR. Kekuatan hubungan variabel-variabel bebas tersebut dengan pemberian ASI eksklusif apabila diurutkan dari yang terbesar ke yang terkecil yaitu pendidikan ibu $(\mathrm{OR}=$ 4,983) dan pendapatan keluarga $(\mathrm{OR}=0,254)$. Hal ini menunjukkan bahwa tingkat pendapatan keluarga yang rendah mempunyai peluang sebesar 0,254 kali lebih besar untuk memberikan ASI eksklusif dibanding dengan tidak memberikan ASI eksklusif, sedangkan untuk tingkat pendidikan ibu yang tinggi mempunyai peluang sebesar 4,983 kali lebih besar untuk memberikan ASI eksklusif dibanding dengan tidak memberikan ASI eksklusif. Hasil ini menunjukkan hubungan yang saling berkaitan antara tingkat pendapatan keluarga dan tingkat pendidikan ibu terhadap pemberian ASI eksklusif. Penelitian ini dilakukan dengan desain cross sectional yang berarti pengamatan dilakukan dalam satu waktu yang bersamaan sehingga tidak dapat mongontrol variabel luar dan variabel perancu secara maksimal. Untuk pengukuran yang dilakukan pada penelitian ini menggunakan kuisioner.

\section{Simpulan}

Kesimpulan yang diambil dalam penelitian ini terdapat hubungan signifikan antara tingkat pendapatan keluarga dan tingkat pendidikan ibu terhadap pemberian ASI eksklusif.

\section{Daftar Pustaka}

1. Fakhidah, L. N., \& Rosita, S. H. (2019). Dukungan Suami dengan Kesiapan Ibu dalam Pemberian ASI pada Bayi di Puskesmas Bulu Kabupaten Sukoharjo. Jurnal Publikasi Kebidanan, 10(1), 70-79.

2. Fithriana, D., Azamti, B. N., \& Apriani, S. Z. (2017). Hubungan Breastfeeding Father dengan Keberhasilan Pemberian Asi Eksklusif pada Bayi di Desa Rumbuk Timur Wilayah Kerja Puskesmas Sakra. Prima Jurnal, 3(2), 7-14.

3. Hastuti, B. W., Machfudz, S., \& Febriani, T. B. (2015). Hubungan Pengalaman Menyusui dan Tingkat Pendidikan Ibu dengan Pemberian ASI Eksklusif di Kelurahan Barukan, Kecamatan Manisrenggo, Kabupaten Klaten. JKKI, 6(4), 179-187.

4. Hety, D. S. (2018). Tingkat Ekonomi terhadap Minat Ibu dalam Pemberian Asi Eksklusif pada Bayi Usia 0-6 Bulan di Ponkesdes Salen Kecamatan Bangsal Kabupaten Mojokerto. Hospital Majapahit, 10(2), 1-13.

5. Kemenkes. (2017). Profil kesehatan Indonesia. Jakarta: Kementrian Kesehatan Republik. 
6. Kemenkes. (2017). Profil Kesehatan Provinsi Jawa tengah Tahun 2017. Jawa Tengah: Kementrian Kesehatan RI.

7. Maulida, H., Afifah, E., \& Sari, D. P. (2015). Tingkat Ekonomi dan Motivasi Ibu dalam Pemberian ASI Eksklusif pada Bayi Usia 0-6 Bulan di Bidan Praktek Swasta (BPS) Ummi Latifah Argomulyo, Sedayu Yogyakarta. Jurnal Ners dan Kebidanan Indonesia, 3, 116-122.

8. Nilakesuma, A., Jurnalis, Y. D., \& Rusdji, S. R. (2015). Hubungan Status Gizi Bayi dengan Pemberian ASI Eksklusif, Tingkat Pendidikan Ibu dan Status Ekonomi Keluarga di Wilayah Kerja Puskesmas Padang Pasir. Jurnal Kesehatan Andalan, 4(1), 37-44.

9. Okafor, C. B., Anarado, A. N., Jisieike Onuigbo, N. N., Chinweuba, A. U., Chikeme, P. C., \& Splendor, C. N. (2019). Exclusive Breastfeeding Knowledge, Intention to Practice and Predictors among Primiparous Women in Enugu South-East, Nigeria. Hindawi Journal of Pregnancy, 1-8.

10. Sihombing, S. (2018). Hubungan Pekerjaan dan Pendidikan Ibu dengan Pemberian ASI Eksklusif di Wilayah Kerja Puskesmas Hinai Kiri Tahun 2017. Jurnal Bidan "Midwife Journal", 5(1), 40-45. 